\title{
EFFECT OF 1,8-DIHYDROXY-9-ANTHRONE (ANTHRALIN) ON RAT HEPATIC ORNITHINE DECARBOXYLASE ACTIVITY IN VIVO
}

\author{
A. BISSCHOP ${ }^{a}$, P.M.J. VANKAN ${ }^{a}$, B. UIJTEWAAL ${ }^{a}$ and R. VAN WIJK ${ }^{b}$ \\ ${ }^{a}$ Laboratory for Carcinogenesis and Mutagenesis, National Institute of Public Health and \\ Environmental Hygiene, P.O. Box 1, 3720 BA Bilthoven and bepartment of Molecular \\ Cell Biology, State University of Utrecht, Padualaan 8, 3584 CH Utrecht (The \\ Netherlands)
}

(Received 27 February 1983)

(Accepted 2 April 1984)

\section{SUMMARY}

Intraperitoneal injection of the non-phorbol tumor promoter anthralin (1,8-dihydroxy-9-anthrone) in male rats resulted in an increase of hepatic ornithine decarboxylase (ODC) activity. Maximal activity was observed $8 \mathrm{~h}$ after promoter administration reaching levels about 30 times over control. The kinetics of anthralin dependent ODC induction differed markedly from that by either 12-O-tetradecanoylphorbol-13-acetate (TPA) or phenobarbital (PB) (Bisschop et al., Carcinogenesis 2 (1981) 1282). With anthralin a slow decrease of ODC back to control level is observed approximately within $22 \mathrm{~h}$. In contrast, ODC induction mediated by other tumor promoters like TPA and PB decreased to control levels within $4-6$ hours. Administration of a second dose of anthralin $8 \mathrm{~h}$ after the first dose prevented the activity decrease as normally observed after a single dose of a tumor promoter. This effect lasted at least $10 \mathrm{~h}$. ODC activity induction occurred in a dosedependent manner being linear from 10-2000 $\mu \mathrm{g}$ anthralin $/ \mathrm{kg}$ body wt. Pretreatment of the animals either with actinomycin D or with cycloheximide completely blocked anthralin mediated ODC induction suggesting that de novo ODC-mRNA synthesis and subsequent translation is involved in this process.

\section{INTRODUCTION}

Anthralin in dilute preparations has been used for many years in the treatment of psoriasis and other skin lesions [20]. Many people are frequently exposed to anthralin especially since its occurrence in cigarette-smoke con- 
densate [25], a reason why anthralin is a possible carcinogenic risk factor for humans. The compound is of interest because of its tumor promoting activity in mouse skin, as was first reported by Bock and Burns [4] and later confirmed by Segal et al. [22].

Recently it was demonstrated that an analogue of anthralin, 1,8-dihydroxy-3-methyl-9-anthrone, also possessed tumor promoting activity in mouse skin, while no initiating activity could be ascribed to anthralin [8]. In all the 2-stage mouse skin carcinogenesis studies 7,12-dimethylbenz [a]anthracene served as the initiating agent $[4,8,22]$.

Despite these facts, research on the mechanism of action of anthralin has received relatively little attention compared to a series of structural closely related skin tumor promoters, the phorbol esters. Among the diversity of effects of TPA in mouse epidermal cells in vitro as well as in vivo and of other non-phorbol tumor promoters in several other cells or tissues, the induction of ODC is regarded as a potentially important feature in the process of tumor promotion. Observations on anthralin mediated regulation of ODC are paradoxal. Anthralin alone is capable of inducing ODC in mouse epidermis $[14,19]$ but pretreatment of mouse skin with low levels of anthralin can significantly suppress the TPA-mediated induction of ODC $[6,7]$ and inhibits TPA-mediated skin tumorigenesis most probably in this way [7].

It was shown recently that TPA is also effective as an inducer of ODC in other than epidermal cells or tissues $[1,2,11,13,27,29]$. These facts and the more general importance of investigations on the effects of non-phorbol tumor promoters in different tissues on the biochemical level led us to study the induction of ODC by anthralin in rat liver.

\section{MATERIALS AND METHODS}

\section{Animals}

Male Wistar derived rats (Cpb:WU[M], 3-4 weeks old, weight $\pm 50 \mathrm{~g}$ ), were used throughout the experiments. Treatment of the animals with tumor promoter occurred by i.p. injection.

\section{Enzyme assays}

ODC activity in the liver supernatants, prepared as earlier described, was assayed by measuring the liberation of ${ }^{14} \mathrm{CO}_{2}$ at $37^{\circ} \mathrm{C}$ from $0.5 \mu \mathrm{Ci} \mathrm{L}-\left[1-{ }^{14} \mathrm{C}\right]$ ornithine $[1-3,21,26]$. Protein content of the liver supernatants was determined by the method of Lowry et al. [16].

\section{RESULTS}

Intraperitoneal injection of $8.8 \mu \mathrm{mol}$ anthralin $/ \mathrm{kg}$ body wt caused rat liver ODC activity to increase rapidly with a lag time of $\sim 2 \mathrm{~h}$ to a maximum reached after $8 \mathrm{~h}$ (Fig. 1). Maximal stimulation of ODC activity was $\sim 30$ - 


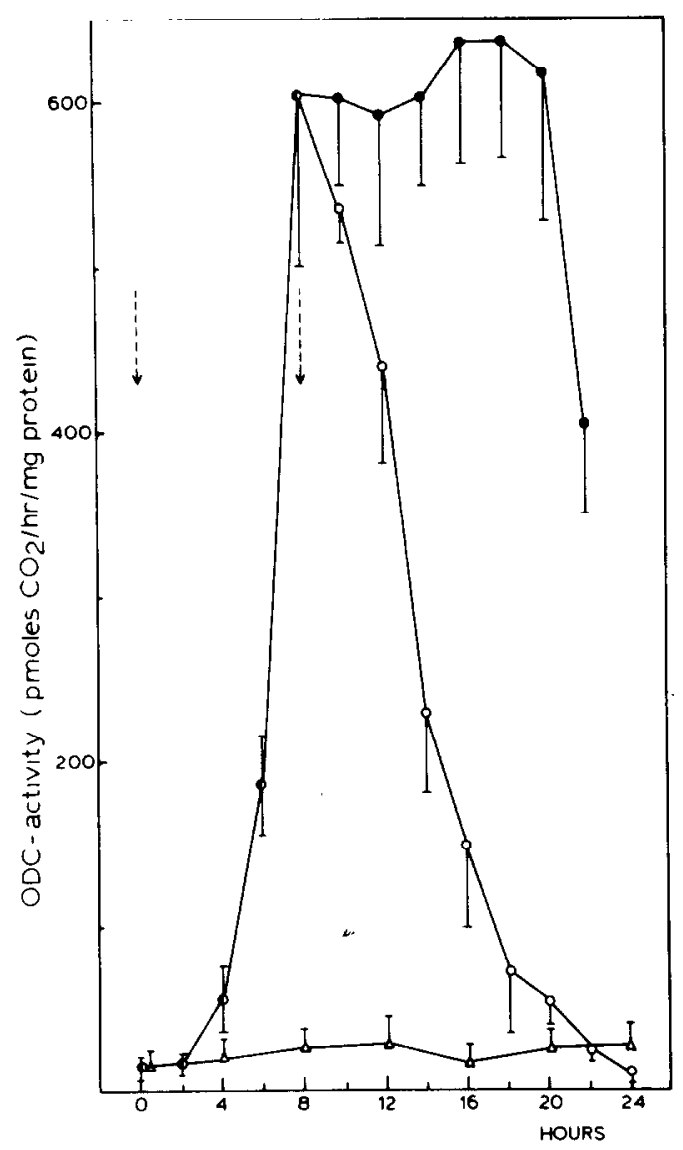

Fig. 1. Time course of rat liver ODC induction after i.p. injection(s) of anthralin. Rats received a single $(0)$ i.p. injection of $2 \mathrm{mg}(8.8 \mu \mathrm{mol})$, anthralin $/ \mathrm{kg}$ body wt or an equal second dose $(\bullet)$ at the times indicated by the arrows. Control rats $(\Delta)$ received $2.5 \mathrm{ml} / \mathrm{kg}$ body wt propyleneglycol. At different times after tumor promoter treatment rats were killed by decapitation and the livers were excised, homogenised and subsequently centrifuged for $105,000 \times \mathrm{g}$ to yield supernatants that were assayed in triplicate for ODC activity. Each point represents the mean of 6 individual rat liver supernatants. Vertical bars, S.D.

fold as compared with control level and the increase had an exponential character. After the maximum was reached a relatively slow decrease back to control level was observed. The exponential decay $\left(t_{1 / 2}=2.7 \mathrm{~h}\right)$ of ODC activity started $10 \mathrm{~h}$ after anthralin administration. When a second dose of anthralin was given $8 \mathrm{~h}$ following an equal initial dose of $8.8 \mu \mathrm{mol} / \mathrm{kg}$ body $\mathrm{wt}, \mathrm{ODC}$ activity first remained constant. Then, it started to decrease $10 \mathrm{~h}$ after the second application (Fig. 1). Apparently, liver ODC was induced by anthralin and was maintained at induced level by repeated injection. This suggests that the decrease of ODC activity after a single injection is caused by loss (excretion or metabolism) of anthralin. 


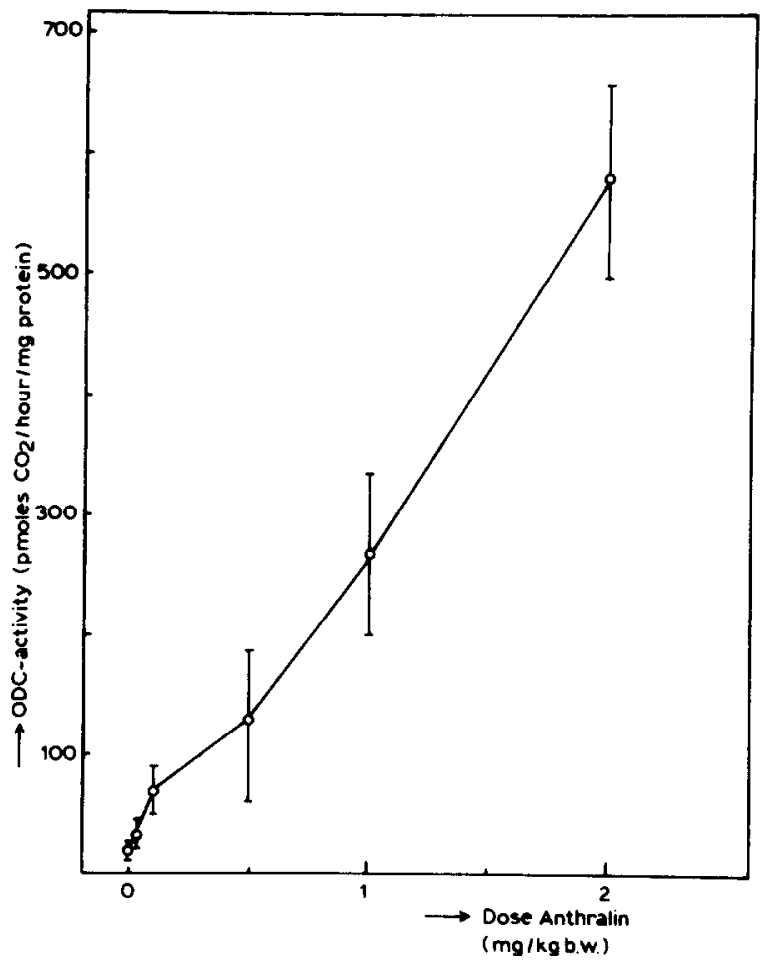

Fig. 2. Relationship between doses of anthralin and ODC activity. Groups of 6 rats were given doses of anthralin in the range of 10-2000 $\mu \mathrm{g}$ anthralin $/ \mathrm{kg}$ body wt and killed $8 \mathrm{~h}$ after treatment. Vertical bars, S.D.

The effect of increasing doses of anthralin on the induction of ODC activity determined $8 \mathrm{~h}$ after application of the tumor promoter is shown in Fig. 2. In the dose range of $10-2000 \mu \mathrm{g}$ anthralin $/ \mathrm{kg}$ body wt, a linear relationship was observed between dose and specific ODC activity. Raising the dose to $10 \mathrm{mg}$ anthralin $/ \mathrm{kg}$ body wt led to premature death of the animals. When rats were pretreated with actinomycin $D(1.6 \mu \mathrm{mol} / \mathrm{kg}$ body wt $)$ or cycloheximide $(178 \mu \mathrm{mol} / \mathrm{kg}$ body wt) the anthralin mediated ODC induction was completely blocked (Table 1 ). This suggests that the tumor promoter activates the ODC gene resulting in de novo synthesis of ODC.

\section{DISCUSSION}

The rat hepatic ODC induction kinetics after administration of anthralin differs considerably from that observed with TPA, PB or $N$-hydroxy-2acetyl-aminofluorene in rat liver where after a lag time of $2 \mathrm{~h}$ a maximum is reached at $4 \mathrm{~h}$ and activity returns to control level $6 \mathrm{~h}$ after treatment $[1-3$, $5,27,28]$. Also in other in vivo or in vitro systems, a similar kinetics of ODC induction caused by tumor promoters was observed $[18,19,29]$. Anthralin- 
TABLE 1

EFFECT OF ACTINOMYCIN D AND CYCLOHEXIMIDE ON ANTHRALINDEPENDENT LIVER ODC INDUCTION

\begin{tabular}{llcc}
\hline $\begin{array}{l}\text { Treatment } \\
\text { anthralin }\end{array}$ & Inhibitor & \multicolumn{2}{c}{ Specific activity of $\mathrm{ODC}\left(\mathrm{pmol} \mathrm{CO}_{2} / \mathrm{h} / \mathrm{mg}\right.$ protein $)$} \\
\cline { 2 - 3 } & & $\begin{array}{l}4 \mathrm{4} \text { after } \\
\text { anthralin }\end{array}$ & $\begin{array}{l}\text { 8 h after } \\
\text { anthralin }\end{array}$ \\
\hline- & $22.0 \pm 8$ & $12.0 \pm 2$ \\
+ & $56.0 \pm 19$ & $606.0 \pm 103$ \\
+ & - & $0.3 \pm 0.1$ & N.D. \\
- & - & $0.5 \pm 0.1$ & $0.3 \pm 0.1$ \\
+ & Cycloheximide & Cycloheximide & $16.0 \pm 4$ \\
- & Actinomycin D & $14.0 \pm 4$ & $10.0 \pm 2$ \\
\hline
\end{tabular}

Group of 6 rats received an i.p. dose of $2 \mathrm{mg}$ anthralin $/ \mathrm{kg}$ body wt $(0.8 \mathrm{mg}$ anthralin $/ \mathrm{ml}$ propyleneglycol). Rats received $1 \mathrm{~h}$ prior to anthralin injection, either $50 \mathrm{mg}$ cycloheximide $/ \mathrm{kg}$ body wt $(5 \mathrm{mg} / \mathrm{ml} 0.9 \%$ saline $)$ or $2 \mathrm{mg}$ actinomycin $\mathrm{D} / \mathrm{kg}$ body wt $(0.2 \mathrm{mg} / \mathrm{ml}$ $0.9 \%$ saline). Control animals received $2.5 \mathrm{ml} 0.9 \%$ saline $/ \mathrm{kg}$ body wt $1 \mathrm{~h}$ prior to anthralin. Eight hours after application of the tumor promoter the rats were killed and ODC activities were measured in liver supernatants. Mean values are given with S.D.

a N.D. not determined.

mediated ODC induction is a process that is sensitive to actinomycin D and cycloheximide, comparable to that described for TPA in rat liver [1] and in primary mouse epidermal cells [15].

Moreover, ODC induction by phorbol esters in mouse skin [24] and rat liver (unpublished) are characterized by the process of down regulation which means that once the activity starts to decrease, it is not possible to re-induce ODC for a certain period of time. In contrast, anthralin maintained inducibility by a second application.

It is known for TPA that binding to the receptor is followed by downmodulation of the receptor proteins $[10,23]$ resulting in a temporary refractoriness of the cells for a following stimulation is often accompanied with de-induction. Instead, decrease of anthralin-mediated ODC activity can be the result of loss of (active) inducer and decrease of translatable ODC-mRNA by turnover, which has a half life of $\sim 2 \mathrm{~h}$ [ 17 and Refs. therein]. Besides the different effect on the induction of ODC, anthralin differs in several other hiochemical responses from tumor promoting phorbol esters. In contrast to TPA, anthralin has no effect on the incorporation of choline in phosphatidylcholine in HeLa cells [12]. TPA treatment causes sister chromatid exchanges in V79 cells while anthralin does not [9]. A possible explanation may be that despite their common sites of action anthralin and the tumor promoting phorbol esters exert their effects at different cellular sites. In relation to the present study with anthralin it would be valuable to investigate the interaction with TPA, since there is a common site of interaction of TPA and 
anthralin because of the inhibitory effect of anthralin on TPA-mediated induction of ODC $[6,7]$.

\section{ACKNOWLEDGEMENTS}

The authors wish to express their gratitude to J. van Soolingen, J. Beenen and F.M. Broere for their biotechnical assistance, and to M. LamersDalloyaux for typing the manuscript. Dr. C.A. van der Heijden is greatly acknowledged for critical discussion of the manuscript.

\section{REFERENCES}

1 Bisschop, A., Rooijen, L.A.A.van, Derks, H.J.G.M. and Wijk, R.van (1981) Induction of rat hepatic ornithine decarboxylase by the tumor promoters 12 -O-tetradecanoylphorbol-13-acetate and phenobarbital in vivo; effect of retinyl-acetate. Carcinogenesis, 2, 1282-1287.

2 Bisschop, A. and Rooijen, L.A.A.van (1982) Modulation by indomethacin, prostaglandins and retinylacetate of rat liver ornithine decarboxylase activity by tumor promoters in vivo. In: Prostaglandins and Related Lipids, Vol. 2, Prostaglandins and Cancer: First International Conference pp. 273-280. Editors: T.J. Powles, R.S. Bockman, K.V. Honn and R. Ramwell. Alan R. Liss, Inc., New York.

3 Bisschop, A., Bakker, O., Meerman, J.H.N., Wijk, R.van, Heijden C.A.van der and Stavenuiter, J.F.C. (1984) Induction of ornithine decarboxylase and augmentation of tyrosine aminotransferase activity by $\mathrm{N}$-hydroxy-2-acetylaminofluorene and 2-acetylaminofluorene in rat liver. Influence of sex, retinyl-acetate, indomethacin and pentachlorophenol. Cancer Investigations, in press.

4 Bock, F.G. and Burns, R. (1963) Tumor-promoting properties of anthralin $(1,8,9-$ anthratriol). J. Natl. Cancer Inst., 30, 393-397.

5 Buys, C.V. and Weiner, R.A. (1982) Tumor promoting phorbol-ester derivatives increase ornithine decarboxylase activity and poly amine biosynthesis in the liver of rat and mouse. Carcinogenesis, 3, 751-755.

6 De Young, L.M. and Sun, V. (1979) Anthralin mediated suppression of tetradecanoylphorbol-acetate induced mouse epidermal ornithine decarbox ylase activity and DNA synthesis. Clin. Res., 27, 524A.

7 De Young, L.M., Helmes, C.T., Chao, W.R., Young, J.M. and Miller, V. (1981) Paradoxal effect of anthralin on 12-O-tetradecanoylphorbol-13-acetate-induced mouse epidermal ornithine decarboxylase activity, proliferation, and tumor promotion. Cancer Res., 41, 204-208.

8 DiGiovanni, J. and Boutwell, R.K. (1983) Tumor promoting activity of 1,8-dihydroxy-3-methyl-9-anthrone (chrysarobin) in female SENCAR mice. Carcinogenesis, $4,281-284$.

9 Huberman, E., Mc.Keown, C.K. and Friedman, J. (1981) Multagen-induced resistance to mycophenolic acid in hamster cells can be associated with increased inosine $5^{\prime}$ phosphate dehydrogenase activity. Proc. Natl. Acad. Sci. U.S. A., 78, 3151-3154.

10 Jaken, S., Tashjian, Jr., A.H. and Blumberg, P.M. (1981) Characterization of phorbol ester receptors and their down-modulation in $\mathrm{GH} 4 \mathrm{C} 1$ rat pituitary cells. Cancer Res., $41,2175-2181$.

11 Kinzel, V., Richards, J. and Stöhr, M. (1981) Early effects of the tumor promoting phorbol ester 12-O-tetradecanoylphorbol-13-acetate on the cell cycle traverse of asynchronous HeLa cells. Cancer Res., 41, 300-305.

12 Kinzel, V., Kreibich, G., Hecker, E. and Süss, R. (1979) Stimulation of choline incor- 
poration in cell cultures by phorbol derivates and its correlation with their irritant and tumor-promoting activity. Cancer Res., 39, 2743-2750.

13 Kishore, G.S. and Boutwell, R.K. (1981) Induction of mouse hepatic ornithine decarboxylase by skin application of 12-0-tetradecanoylphorbol-13-acetate. Experientia, $37,179-180$.

14 Lichti, U., Yuspa, S.H. and Hennings, H. (1978) Ornithine and S-adenosylmethionine decarboxylases in mouse epidermal cell cultures treated with tumor promoters. In: Carcinogenesis. Mechanism of Tumor Promotion and Cocarcinogenesis, Vol. 2, pp. 221-232. Editors: T.J. Slaga, A. Sivak and R.K. Bou twell. Raven Press, New York.

15 Lichtli, U., Patterson, E., Hennings, H. and Yuspa, S.H. (1981) Differential retinoic acid inhibition of ornithine decarboxylase induction by 12-O-tetradecanoylphorbol13-acetate and by germicidal-ultraviolet light. Cancer Res., 41, 300-305.

16 Lowry, O.H., Rosebrough, N.J. Farr, A.L. and Randall, R.J. (1951) Protein measurement with the Folin phenol reagent. J. Biol. Chem., 193, 265-275.

17 Maudsley, D.V. (1979) Commentary. Regulation of polyamine biosynthesis. Biochem. Pharmacol., 28, 153-161.

18 Mufson, R.A., Fischer, S.M., Verma, A.K., Gleasen, G.L. and Boutwell, R.K. (1979) Effects of 12-O-tetradecanoylphorbol-13-acetate and mezerein on epidermal ornithine decarboxylase activity, isoproterenol-stimulated levels of C-adenosine $3^{\prime}: 5^{\prime}$-monophosphate, and induction of mouse skin tumors in vivo. Cancer Res., 39, 4791-4795.

19 O'Brien, T.G., Simisiman, R.C. and Boutwell, R.K. (1975) Induction of the polyamine-biosynthetic enzymes in mouse epidermis and their specificity for tumor promotion. Cancer Res., 35, 2426-2433.

20 Perutz, A. (1930) Die Pharmakologie der Haut. In: Handbuch der Haut und Geschlechtskrankheiten, Vol. 5, p. 155, Editor: J. Jadassohn. Julius Springer, Berlin.

21 Russell, D.H. and Snyder, S.H. (1968) Amine syn thesis in rapidly growing tissues: ornithine decarboxylase activity in regenerating rat liver, chick embryo, and various tumors. Proc. Natl. Acad. Sci. U.S.A., 60, 1420-1427.

22 Segal, A., Katz, C. and Van Duuren, B.L. (1971) Structure of tumor-promoting activity of anthralin (1,8-dihydroxy-9-anthrone) and related compounds. J. Med. Chem., 14, 1152-1154.

23 Solanki, V. and Slaga, T.J. (1982) The down-modulation of receptors for phorbol ester tumor promoter in primary epidermal cells. Carcinogenesis, 3, 993-998.

24 Takigawa, M., Simsiman, R.C. and Boutwell, R.K. (1983) The difference between the effects of single and double applications of 12-O-tetradecanoylphorbol-13-acetate, a potent tumor promoter, on polyamine metabolism and nucleic acid synthesis in mouse epidermis. Carcinogenesis, 4, 5-7.

25 Van Duuren, B.L. and Goldschmidt, B.M. (1976) Cocarcinogenesis and tumor-promoting agents in tobacco carcinogenesis. J. Natl. Cancer Inst., 56, 1.237-1242.

26 Wijk, R.van, Louwers, H.A.P.M. and Bisschop, A. (1981) The induction of ornithine decarboxylase and DNA synthesis in rat hepatocytes after a single administration of dieth ylnitrosamine. Carcinogenesis, 2, 34-38.

27 Weiner, R.A. and Byus, C.V. (1980) Induction of ornithine decarboxylase by 12-0tetradecanoylphorbol-13-acetate in rat tissues. Biochem. Biophys. Res. Commun., 97, 1575-1581.

28 Yanagi, S., Sasaki, K. and Yamamoto, N. (1981) Induction by phenobarbital of ornithine decarboxylase in rat liver after initiation with diethylnitrosamine. Cancer Letters, 12, 87-91.

29 Yuspa, S.H., Lichti, U., Ben, T., Patterson, E., Hennings, H., Slaga, T.J., Colburn, N.H. and Kelsey, E. (1976) Phorbol esters stimulate DNA synthesis and ornithine decarboxylase activity in mouse epidermal cell cultures. Nature, 262, 402-404. 